\title{
Short Titles and Abbreviations
}

$A V$ : Authorized ("King James") Version of the Bible

Ann. Reg.: The Annual Register, 1758-63.

Applause: Boswell: The Applause of the Jury, $I 782-I 785$, edited by I. S. Lustig and F. A. Pottle. London: Heinemann, i98r.

Bailey: James Boswell, The Hypochondriack: Being the Seventy Essays by the Celebrated Biographer James Boswell, Appearing in the London Magazine from November, I777, to August, I783, and Here First Reprinted, edited by Margery Bailey. 2 vols. Stanford, CA: Stanford University Press, 1928.

Boswelliana: Boswelliana: The Commonplace Book of James Boswell, edited by Charles Rogers. London, 1874.

Brewer's Dict.: Brewer's Dictionary of Phrase E Fable, edited by Camilla Rockwood. 18th ed. Edinburgh: Chambers, 2 oro.

Cat. Yale: Marion S. Pottle, Claude Colleer Abbott, and Frederick A. Pottle, Catalogue of the Papers of James Boswell at Yale University: For the Greater Part Formerly the Collection of Lieut.-Colonel Ralph Heyward Isham. Vol. 3. Edinburgh: Edinburgh University Press; New Haven: Yale University Press, 1993.

Corres. I: The Correspondence of James Boswell and John Johnston of Grange, edited by Ralph S. Walker. London: Heinemann, 1966.

Corres. 2: The Correspondence and Other Papers of James Boswell Relating to the Making of the "Life of Johnson," edited by Marshall Waingrow. 2nd ed., corrected and enlarged. Edinburgh: Edinburgh University Press; New Haven: Yale University Press, 200I.

Corres. 3: The Correspondence of James Boswell with Certain Members of the Club, including Oliver Goldsmith, Bishops Percy and Barnard, Sir Joshua Reynolds, 
Topham Beauclerk, and Bennet Langton, edited by Charles N. Fifer. London: Heinemann, 1976.

Corres. 4: The Correspondence of James Boswell with David Garrick, Edmund Burke, and Edmond Malone, edited by Peter S. Baker, Thomas W. Copeland, George M. Kahrl, Rachel McClennan, and James M. Osborn, with the assistance of Robert Mankin and Mark Wollaeger. London: Heinemann, 1986.

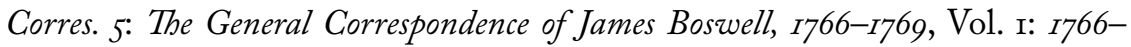
I767, edited by Richard C. Cole, with Peter S. Baker and Rachel McClellan, with the assistance of James J. Caudle. Edinburgh: Edinburgh University Press, 1993.

Corres. 6: The Correspondence of James Boswell and William Johnson Temple, I7561795, Vol. I: ${ }_{775}-1777$, edited by Thomas Crawford. Edinburgh: Edinburgh University Press; New Haven: Yale University Press, 1997.

Corres. 7: The General Correspondence of James Boswell, I766-I769, Vol. 2: I768I769, edited by Richard C. Cole, with Peter S. Baker and Rachel McClellan, with the assistance of James J. Caudle. Edinburgh: Edinburgh University Press; New Haven: Yale University Press, 1997.

Corres. 9: The General Correspondence of James Boswell, $1757^{-1763}$, edited by David Hankins and James J. Caudle. Edinburgh: Edinburgh University Press; New Haven: Yale University Press, 2006.

Defence: Boswell for the Defence, $1769-1774$, edited by W. K. Wimsatt and F. A. Pottle. London: Heinemann, r96o.

Earlier Years: F. A. Pottle, James Boswell: The Earlier Years, I740-I769. London: Heinemann, 1966.

Experiment: Boswell: The English Experiment, $1785-1789$, edited by I. S. Lustig and F. A. Pottle. London: Heinemann, 1986.

Extremes: Boswell in Extremes, $1776-1778$, edited by C. McC. Weis and F. A. Pottle. New York: McGraw-Hill, I970.

Fasti Scot:: Hew Scott, Fasti Ecclesiae Scoticanae: The Succession of Ministers in the Church of Scotland from the Reformation. 7 vols. Edinburgh: Oliver and Boyd, I915-28.

Gent. Mag.: The Gentleman's Magazine, 173-1907.

Grand Tour I: Boswell on the Grand Tour: Germany and Switzerland, I764, edited by F. A. Pottle. London: Heinemann, 1953.

Grand Tour 2: Boswell on the Grand Tour: Italy, Corsica, and France, I765-I766, edited by Frank Brady and F. A. Pottle. London: Heinemann, I955.

Grant: James Grant, Cassell's Old and New Edinburgh: Its History, Its People, and Its Places. 6 vols. London, I88I-88. http://www.oldandnewedinburgh.co.uk. 
Great Biographer: Boswell: The Great Biographer, I789-I795, edited by Marlies K. Danziger and Frank Brady. London: Heinemann, I989.

HLP: Hester Lynch Piozzi.

Holland: Boswell in Holland, I763-I764: Including His Correspondence with Belle de Zuylen (Zelide), edited by F. A. Pottle. London: Heinemann, I952.

JB: James Boswell.

Laird: Boswell, Laird of Auchinleck, I778-I782, edited by J. W. Reed and F. A. Pottle. New York: McGraw-Hill, 1977.

Later Years: Frank Brady, James Boswell: The Later Years, I769-1795. London: Heinemann, 1984.

Letters JB: Letters of James Boswell, edited by C. B. Tinker. 2 vols. Oxford: Clarendon, 1924 .

Letters SJ: The Letters of Samuel Johnson, edited by Bruce Redford. 5 vols. Princeton, NJ: Princeton University Press, 1992-94.

Life: Boswell's Life of Johnson, together with Boswell's Journal of a Tour to the Hebrides and Johnson's Diary of a Journey into North Wales, edited by G. B. Hill, revised by L. F. Powell. 6 vols. Oxford: Clarendon, I934-50; vols. V and VI. and ed. Oxford: Clarendon, I964.

Lit. Anec.: John Nichols, Literary Anecdotes of the Eighteenth Century. 9 vols. London, I8I2-I5.

Lit. Car.: F. A. Pottle, The Literary Career of James Boswell, Esq.: Being the Bibliographical Materials for a Life of Boswell. Oxford: Clarendon, I929.

Lond. Chron.: The London Chronicle, I757-1823.

Lond. Journ.: Boswell's London Journal, $I 762-I 76_{3}$, edited by F. A. Pottle. London: Heinemann, I950.

NCBEL: The New Cambridge Bibliography of English Literature, edited by George Watson. Vol 2. Cambridge: Cambridge University Press, I97I.

ODNB: Oxford Dictionary of National Biography, edited by Brian Harrison and Lawrence Goldman, founding editor Colin Matthew. Oxford: Oxford University Press, 2004-IO.

ODQ: Oxford Dictionary of Quotations, edited by Elizabeth Knowles. 7 th ed. Oxford: Oxford University Press, 2009.

OED: Oxford English Dictionary Online.

Ominous Years: Boswell: The Ominous Years, $I 774-1776$, edited by Charles Ryskamp and F. A. Pottle. London: Heinemann, ig63.

P + number: reference to "Printed matter" in vol. 3 of Cat. Yale (see above).

Parl. Hist.: The Parliamentary History of England from the Earliest Period to the Year 1803.36 vols. London, I806-20. 
Pol. Car.: Frank Brady, Boswell's Political Career. New Haven: Yale University Press, 1965 .

Pub. Adv.: The Public Advertiser, $1752-94$.

St. James's Chron.: The St. James's Chronicle; or, British Evening-Post, 1766-1866.

Scots Mag.: The Scots Magazine, I739-1817.

Search: Boswell in Search of a Wife, I766-I769, edited by Frank Brady and F. A. Pottle. London: Heinemann, 1957.

SJ: Samuel Johnson.

SJ Dict.: Samuel Johnson, $A$ Dictionary of the English Language: In which the Words are Deduced from Their Originals and Illustrated in Their Different Significations by Examples from the Best Writers. 2 vols. London, $\mathrm{I} 755$.

Tour: Boswell's Journal of a Tour to the Hebrides. References are to vol. 5 of the Life (see above) unless otherwise indicated. 